\title{
Acquired Factor X Deficiency
}

National Cancer Institute

\section{Source}

National Cancer Institute. Acquired Factor X Deficiency. NCI Thesaurus. Code C131626.

An acquired coagulation disorder characterized by the partial or complete absence of factor X activity in the blood. 